\title{
RISK MANAGEMENT DEBATE FOCUSED ON BANKING INDUSTRY
}

\author{
Eugenia Ana MATIS ${ }^{1}$ \\ Dimitrie Cantemir Christian University Cluj Napoca, Romania \\ Cosmin Dumitru MATIS ${ }^{2}$ \\ Babes-Bolyai University Cluj Napoca, Romania \\ Jiři STROUHAL ${ }^{3}$ \\ Škoda Auto University Mladá Boleslav, Czech Republic
}

\begin{abstract}
Corporate governance is a subject of constant timeliness and broad interest, mainly aimed at ensuring adequate protection for investors and financial institutions. This interest in corporate governance is due to its influence on the healthy growth of companies and society as a whole. Paper provides evidence on implementation of Basel II and Basel III within Romanian banking sector from the historical perspective trying to show an overview on Basel developments and encourages further investigations into the particularities of the Basel III which is soon to be put into practice.
\end{abstract}

\section{KEY WORDS}

Basel II, Basel III, corporate governance, banking sector, Romania

\section{JEL CLASSIFICATION}

G20

\section{INTRODUCTION}

The concept of corporate governance has many definitions, because of the complex elements it covers. Basically, corporate governance is the system which companies are directed and controlled by. Corporate governance structures specify the distribution of rights and responsibilities to the different direct and indirect participants in the work of the company or institution (executives, managers, employees, shareholders, customers, funders) as well as the rules and procedures

\footnotetext{
${ }^{1}$ Correspondence address: Eugenia Ana Matis; Ph.D.; Dimitrie Cantemir University Cluj Napoca, T. Mihali 56, 400591 Cluj Napoca, Romania.

${ }^{2}$ Correspondence address: Cosmin Dumitru Matis; Ph.D. student; Babes-Bolyai University Cluj Napoca, T. Mihali 5860, 400591 Cluj Napoca, Romania.

${ }^{3}$ Correspondence address: Jiří Strouhal; associate professor; ystrouhal@is.savs.cz; Škoda Auto University Mladá Boleslav, Na Karmeli, 1457, 29301 Mladá Boleslav, Czech Republic.
} 
underlying the decision-making process, the establishing of objectives and the methods of achieving and monitoring performance.

The monitoring and management function should be fulfilled within each credit institution. The supervisory authority (National Bank of Romania, hereinafter NBR) will check if the credit institutions have established their decision-making process in terms of hierarchy and responsibilities, according to regulations.

In order to implement an effective corporate governance to manage banking risks, the governing structures of a credit institution have as main tasks the following:

- providing the implementation plan for the IRB approach (internal-rating based) on the most important exposure categories;

- developing the methodology for internal risk rating process;

- identifying and evaluating the events that generate risks;

- monitoring and managing potential sources of conflict of interest;

- establishing responsibilities for the risk control unit and professionally evaluating the staff.

Corporate governance system takes into consideration the following:

- the permanent monitoring of the credit institution activities, the institution's management and the risk control personnel should having to regularly meet to discuss their performance, the areas that need improvement and, not least, the state of the previously identified weaknesses;

- the existence of a risk control unit within each credit institution to carry significant risk control function;

- providing an overall assessment on the adequacy of the internal control system and on the banking risk control function by the internal audit;

- the existence of an internal reporting system, which varies depending on the nature, size and degree of complexity of the credit institution and which is based on the analysis of the institution's risk profile.

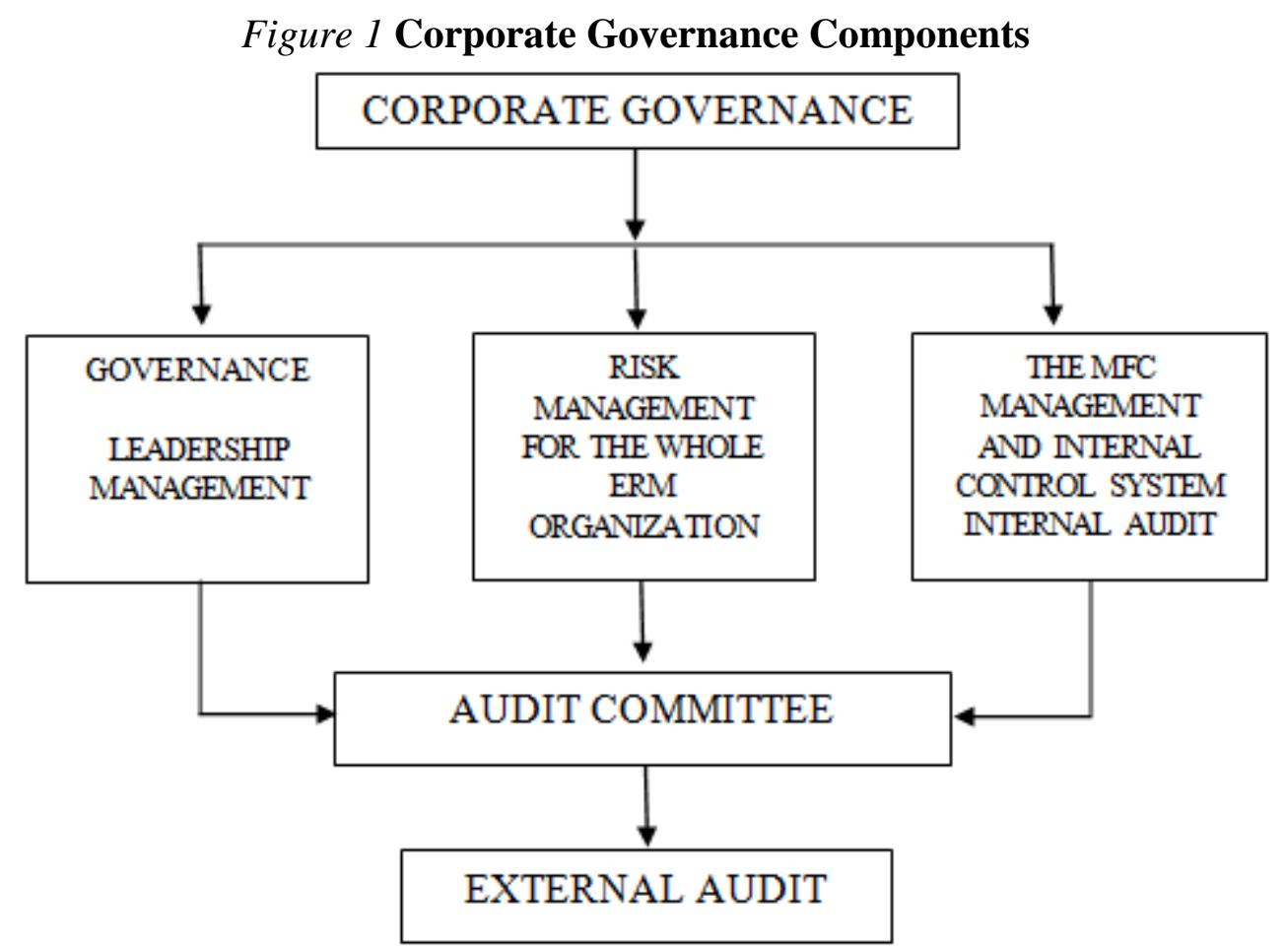

(Source: NBR) 
After the year 2000, corporate governance failures in the financial and banking system stood out, having a strong impact on the society's level of confidence in the credit institutions. Three significant problems stand out according to this point of view:

- imbalances in reward structures;

- neglect of fundamental values by investors and executive management;

- manager's lack of accountability for their actions.

Reward structures. The trend is to include reward structures as part of banking risk management, by providing incentives for the implementation of the deferred compensation plans. According to them, the employee is immediately rewarded with part of the bonus only, the difference being paid after a certain period of time (e.g. one year), when the performance of his work can be confirmed. Another option circulating proposes connecting bonuses and annual awards to certain profit indicators adjusted with the risk.

Core values have changed significantly in recent years, due to the increasingly sophisticated demands, the credit institutions diversifying their activities. Thus, a global risk was generated and because of the claims for even higher profits, the client portfolio has increased. However, human relationships began to lose their original values, because each client was perceived as a quick source of profit rather than a long-term partner. The 2008 financial crisis highlighted even more these problematic issues, often resulting in not understanding their customers, their needs and perspectives.

The responsibility of employees and managers is a new increasingly recognized trend and is based on educating people with regard to the financial and banking system, the products and services it offers, by government and credit institutions.

The basic concept of effective management is based on the idea that risk management is the responsibility of every employee of the credit institution, on every level and functional line. Banking risk management must become a fundamental part of the institution's culture, in addition to respect for the value system and for information.

\section{BASEL I}

The 1988 Basel Agreement established the criteria to be considered for determining the optimal size of a bank's capital and the minimum level of capital that a bank needs to have. The formula set by the Basel Agreement in 1988, simply called Basel I provides precise criteria for capital adequacy. It is important for a bank to have a solid financial basis, to protect it from insolvency. If a bank has a loan portfolio with a high degree of risk, it needs to make sure that it has sufficient financial resources to protect itself in the event of bad loans. Also, a large capital basis protects depositors and maintains their confidence in the bank, being sure that they will not lose money if the bank losses from other activities.

Following the Basel I Agreement, banks in most countries comply with regulations on capital adequacy. This eliminates a certain type of competition, as respecting this requirement restricts banks' ability to attract new customers by simply increasing the volume of granted loans.

According to the Basel I Agreement regulations, banks must have their 1st rank capital proportionate to their assets weighted with the risk at a minimum of $4 \%$, and their 2 nd rank capital of minimum $8 \%$. Currently, most banks in developed countries have a capital adequacy index of at least $10 \%$, the most well capitalized reaching $12 \%$. NBR regulations in the field of capital adequacy 
foresee a minimum index (solvency ratio) of $8 \%$, which is calculated by dividing the equity of banks to the assets (balance-sheet and off balance-sheet) weighted according to risks.

A banking institution's own funds consist of the following categories of capital:

- equity, consists of the paid-in capital, bonus shares, provisions, retained earnings, tangible assets, development fund and other reserves;

- additional capital, which consists of the general reserve for credit risk, subordinated loans, other funds.

In accordance with Basel I, NBR established the following risk percentages on asset categories in the balance sheet: $0 \%$ for cash and deposits with NBR; securities issued by the Romanian central administration and other A countries, international financial institutions, central banks of $\mathrm{A}$ countries; loans and cash advances granted to the Romanian central administration and other A countries, international financial institutions, central eligible participants in the country from category A; other claims on the central Romanian government and other A countries, international financial institutions, central banks of A countries; $20 \%$ for checks, coupons and other items in collection; securities issued by the Romanian banks, A countries banks, local administration in Romania and A countries; loans and cash advances granted to the Romanian banks, A countries banks, B countries banks with date of payment in one year or less, the local government in Romania and other A countries, governmental organizations in Romania and other A countries; cash and deposits in Romanian banks, A countries banks, B countries banks with date of payment in one year or less; other claims over the Romanian banks, A country banks, B country banks with payment day in one year or less, the local government in Romania and other A countries, government organizations in Romania and other A countries; $50 \%$ for loans and cash advances to customers, secured by mortgages on lands and buildings owned by the banking company, for its activity purposes; the total exchange rate position is short; $100 \%$ for other securities, other loans and cash advances, equity ownership in financial institutions and other non-banking entities, other tangible assets, other assets. The NBR also specifies the conversion factors for off-balance sheet elements in credit equivalent as well as the risk percentages on the types of beneficiaries.

The bank insolvency issue has become the subject of debate in the international banking world. Thus, in 1988, the Basel Committee on banking supervision issued a set of rules on capital adequacy standards adjusted for risk. These rules took into consideration reducing the risk by setting a minimum rate of solvency for the international financial and banking institutions. The main objective of the Basel I was to improve bank capitalization and to standardize the action field of competing markets, against insolvency or unexpected losses.

Since 1998, directives of the European Union on financial assets require that activities of financial and banking institutions be divided into two categories: actual financial and banking activities and commercial activities. The first category aims for the main activities of the bank, while the second category refers to the times when banks trade assets on their own on any stock market. European Union directives lay down a method for calculating the risk exposure of the bank during transactions that are highlighted in its record keeping. This is done by updating the market value of their daily positions results, which means calculating the difference between the expected earnings for the original transaction and the cost of acquiring an equivalent transaction the same day.

After the Basel I system was applied, the need to improve its stipulations emerged, due to the complexity of risks in the financial markets. Given this conclusion, derived from the practical application of Basel I system, the central banks governors and heads of bank supervisory authorities in the European Union countries, approved on 26 June 2004, the final version of Basel II. 


\section{CORPORATE GOVERNANCE REQUIREMENTS WITHIN BASEL II}

The publishing of the new own funds adequacy system "International Convergence of Capital Measurement and Capital Standards" is the result of the Basel Committee's activity, which began in 1998. The first Basel Accord was therefore amended in 1996 to allow banks to use internal models for market risks. The agreement became an international principle, for the setting of capital standards, being implemented in over one hundred countries. But its conceptually simple rules became increasingly obsolete for a very complex international banking system in terms of risk management and transactions.

The consultation process continued internationally, with the participation of supervisors, central banks, public authorities and banking and financial institutions. Following these consultations, the Basel Committee issued additional proposals for international consultation in January 2001 and April 2003 and developed three studies on the possible impact. Following the publishing of these studies, they modified the original proposals and approved the new agreement of own funds adequacy for financial and banking institutions in June 2004.

The final version of Basel II, global regulation that establishes a direct link between the equity of financial institutions and the risks they take, was issued at the end of June 2005. Changes from the previous version are notable and banks immediately began to prepare implementation strategies for the new form of the agreement. For banks in Central and Eastern Europe, the implementation of Basel II was a test of their ability to integrate into a wider financial market, European and then global.

The important economic and political changes experienced by the countries of Central and Eastern Europe (CEE) at the time constitute a unique background for the implementation of Basel II. The group of ten joining the European Union in May 2004, and then Romania and Bulgaria in 2007, as well as the strong economic growth in recent years encouraged international banks to create networks in the area.

In addition, the local market has a great potential: it is still under-banked and the demand for financial products increased dramatically, especially in 2003 and 2004. Banks' retail divisions had high growth rates, and forecasts indicate that this trend will continue in the future. Consumer credit increased by $300 \%$ in 2003 compared to 2002. Banking infrastructure is also growing by creating credit bureaus. Therefore, a large share of national bank assets is held by regional or international scale banks. The largest banks in CEE countries are already held by international banks and the process continues with privatization of banks in Albania, Bulgaria and Serbia.

Basel II is a true catalyst for the development of the regional banking market. The European Directive on Capital Adequacy (CAD III) requires that all active banks in the European area implement the agreement until 2007. But in many countries in the region, risk management is not at a very advanced level. Policies and risk management models must be much improved to reach the level of the large banks that use their own internal risk models. If trading volumes or risks presented by the regional branches of international banks are not very important, a more flexible implementation of the Basel II may be chosen with the consent of the national regulator. The main purpose of the Basel II implementation: CAD III will strengthen the Basel II adoption in those CEE countries which are also members of the European Union. CAD III, which will set provision standards for all financial intermediaries, will contribute to the harmonization of the European financial market.

Risk management infrastructure in CEE countries is growing from a very low level and foreign banks must make significant efforts to raise this level. For example, the comparatively low trading 
volumes and lack of historical data makes it difficult for a risk assessment model to be applied. Other problems to be overcome are slow data processing and bureaucracy. In addition, reduced volumes lead to extension of the hardware investment amortization, at least in the short run.

Some international banks have already implemented risk management practices within corporate governance, especially the ones consistent with the transparent collection and processing of data. Although these projects required significant investments and lasted between two and three years, the result was the implementation of flexible and reliable solutions and a first step towards meeting the requirements of the IRB (Internal Rating Based Approach) model. There are a number of factors that encourage national banks to adapt Basel II as soon as possible. First of all, a bank about to implement Basel II is more attractive to potential foreign investors and it can obtain a higher price for its shares. Also, it can easily integrate into a global network. Secondly, after applying Basel II national banking markets will become more competitive, although there is a risk of greater sensitivity to external shocks. On the other hand, one must also take into consideration the fact that the 2008 global economic collapse began to generate question marks when it comes to the effectiveness of the risk management in credit institutions under Basel II system.

\section{IMPLEMENTATION OF BASEL II IN ROMANIAN BANKING SECTOR}

The Basel II capital agreement, adopted by the Basel Committee in 2005, is not an imperative regulation for the national banking systems. However, the Basel Committee's regulations are picked up in international or national standards that are mandatory to apply. It is also the case of the Basel II, picked up by the European Directive, commonly known as CAD III (Capital Adequacy Directive). CAD III has the Banking Consolidation Directive 2000/12/EEC and the Directive for Capital Adequacy of investment companies and credit institutions 93/6/EEC, reconfigured. In the European Union countries, CAD III was implemented starting with 2007 (Matis, 2009).

Once Romania joined the European Union, the preparation of the banking system in order to implement the specific Basel II standards, started. At first, the Romanian banking system, through the decision takers of the central bank and credit institutions, had to understand the stipulations of the new agreement. The next step was to relevantly assess the banking system's development stage, and last but not least, to configure and implement a coherent set of measures in order to adapt the domestic banking system, allowing the application of Basel II system.

The main feature of the new agreement is capital adequacy within credit institutions. In the field of capital adequacy, during the first half of 2006, credit institutions in Romania started applying the national legislation which assumed the stipulations of Basel I agreement, in place since 1988. Banking companies active in Romania, in their capacity of credit institutions, are required to maintain at all times the solvency ratio at a minimum of $12 \%$.

The solvency ratio expresses own funds, as a proportion of total balance-sheet and off balance-sheet assets, net of provisions, adjusted to the risk. The minimum solvency ratio established in our country is higher than the $12 \%$ established by the Basel I, which shows an attitude of caution from the regulatory authority in the field.

According to the 2008 Annual Report of the NBR, with respect to the solvency of the banking system, the solvency ratio has slowed down its descending trend, its level being at $12.30 \%$ at the end of 2008, because of capital increase in credit institutions and reduction of government credit. This remains above the minimum requirement, which is $12 \%$. 
In national law, the NBR Norm no. 17/2003 regulates the management of key banking risks, in accordance with Basel II. This norm stipulates organization and internal control of credit institutions and managing of the significant risks, as well as the organization and internal audit of credit institutions. The regulatory act defines significant banking risks, presents the benchmarks of the internal control system and internal audit that banks must organize. Credit institutions must organize a system of internal control which should identify and assess significant risks.

Identification and evaluation of significant risks should be made at an overall level of a credit institution as well as at all its organizational levels, it must cover all activities and take into account the emergence of new activities. In terms of international provision, the second part of the Basel II Accord presents the calculation of the minimum capital required from the banks, depending on credit risk, market risk and operational risk. Moreover, the new agreement introduces the concept of operational risk, insignificant in the preceding foresights.

Actions taken by the NBR show that the central bank understood the rules of the Basel II system as being complicated and has set up an action plan to meet the challenges of Basel II. The central bank made its concerns in the field public, and established a timetable for implementing the proposed actions.

Understanding the state of the Romanian banking system was the first thing that the central bank established in its priorities as the main pawn of the Basel II in Romania. Being a national banking supervisory authority and having within reach the informational levers with credit institutions, the central bank was able to establish information requirements for banks to report with respect to the current procedures available in the field of risk management. Also, the banks were required to come up with options as to the type of approach they would like to implement in the field of risk management according to the Accord (Matis, 2009).

According to the choices made by the banks in November 2005 in terms of choosing the methods for addressing credit risk, 30 banks opted for the standardized approach, 2 banks for the foundation internal rating-based approach, none for the advanced internal rating-based approach and two banks were not decided at the time. As for the bank's options on operational risk specific approach, 17 banks opted for the basic indicator approach, 13 banks for the standardized approach, 2 banks for advanced measurement approach AMA and two banks did not decided at that time.

The NBR established a Steering Committee in the field of Basel II, composed of The Ministry of Public Finance, The National Securities Commission and The Romanian Association of Banks, institutions which have an impact on the activity of banks (Matis, 2009). This board is based on the information support coming from the experts of the European Commission, who were consulted to facilitate preparations. The NBR presents as following the regulations on the implementation of Basel II in Romania, organized into three pillars:

\section{Table 1 Structure of the Basel II Accord}

\begin{tabular}{|c|c|c|}
\hline $\begin{array}{c}1^{\text {st }} \text { Pillar } \\
\text { Minimum capital } \\
\text { requirements }\end{array}$ & $\begin{array}{c}2^{\text {nd }} \text { Pillar } \\
\text { Capital adequacy } \\
\text { supervision }\end{array}$ & $\begin{array}{c}3^{\text {rd }} \text { Pillar } \\
\text { Market discipline }\end{array}$ \\
\hline $\begin{array}{l}\text { Flexible and advanced rules } \\
\text { for determining minimum } \\
\text { capital requirements for: } \\
\text { - credit risk: } \\
\text {-standardized approach; }\end{array}$ & $\begin{array}{lr}\text { - Active role of the } \\
\text { supervisory authority in } \\
\text { evaluating } & \text { banks' } \\
\text { internal } & \text { procedures } \\
\text { regarding } & \text { capital }\end{array}$ & $\begin{array}{l}\text { More detailed reporting } \\
\text { requirements towards the } \\
\text { NBR and as a novelty, } \\
\text { towards the public, } \\
\text { regarding: }\end{array}$ \\
\hline
\end{tabular}




\begin{tabular}{|c|c|c|}
\hline $\begin{array}{l}\text {-Internal Rating Based } \\
\text { Approach - IRB - foundation } \\
\text { or advanced version } \\
\text { - market risk } \\
\text { - operational risk } \\
\text {-basic indicator approach; } \\
\text {-standardized approach } \\
\text { - advanced measurement } \\
\text { approach (internal models) }\end{array}$ & $\begin{array}{l}\text { adequacy to the risk } \\
\text { profile; } \\
\text { - Checking banks' } \\
\text { internal procedures by } \\
\text { the supervisory } \\
\text { authority; } \\
\text { - Requiring that credit } \\
\text { institutions maintain } \\
\text { capital in excess of the } \\
\text { minimum level } \\
\text { indicated by Pillar I; } \\
\text {-Implementation of } \\
\text { early NBR intervention } \\
\text { mechanisms. }\end{array}$ & $\begin{array}{l}\text { - } \text { shareholding structure } \\
\text { - risk exposure } \\
\text { - capital adequacy to the } \\
\text { risk profile }\end{array}$ \\
\hline
\end{tabular}

(Source: NBR)

\section{CONCLUSIONS}

The implementation of Basel II should lead to the development of the rating agencies, statistical databases and econometric methods for grounding internal models of the banks. As emphasized by Nucu (2011), Basel III, representing a fundamental review of the regulatory and supervision framework of the banking industry in the future, its aim being to strengthen the stability of the financial system, nowadays represents a new challenge for the Romanian banking system. The implementation of the directive on the capital agreement Basel III will be phased in from January 2013 for the European banking system. The process is expected to be concluded by January 2019 . The requirements will be introduced in the EU through the Capital Requirements Directive (CRD) 4, which applies to all EU member states. In this regard the Romanian Banking Association (ARB) has set up a commission on Basel III to implement it, make propositions and seek clarifications (Posirca, 2012). Our historical analysis contributes to developing an overview on Basel developments and encourages further investigations into the particularities of the Basel III which is soon to be put into practice.

\section{REFERENCES}

Basel Committee on Banking Supervision (2004) Basel II - International Convergence of Capital Measurement and Capital Standards - a Revised Framework. Basel Committee on Banking Supervision.

Basel Committee on Banking Supervision (2011). Basel III: A global regulatory framework for more resilient banks and banking systems. Basel Committee on Banking Supervision.

Matis, E.A. (2009) Managementul performantei si riscului in bancile comerciale din Romania. Cluj Napoca: Casa Cartii de Stinta Publishing House.

Nucu, A.E. (2011) The Challenges of Basel III for Romanian Banking System, Theoretical and Applied Economics, vol. 58, no. 12, pp. 59-70.

Posirca, P. (2012) Romanian lenders touch Basel III, Business Review, available at http://businessreview.ro/featured/romanian-lenders-touch-basel-iii/. 